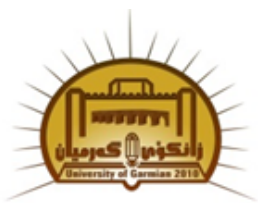

Available online at http://jgu.garmian.edu.krd

Journal of Uni versity of Garmian

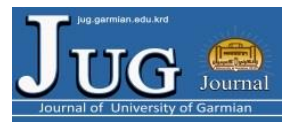

https://doi.org/10.24271/ garmian.196229

\title{
A Sociolinguistic Study of Code-switching in Khanqeeni Kurdish
}

\author{
Jamal Abdul-Rahman Mohammad
}

Kalar Private Institute

\section{Article Info}

Received: April, 2019

Revised:April,2019

Accepted:May,2019

\section{Keywords}

Code-switching , Khanqeeni Kurdish, sociolinguistic

\section{Corresponding Author}

Jamals arqizly@yahoo.com

\begin{abstract}
The study attempts to investigate the phenomenon of code-switching in conversation between the Kurds bilingual speakers in khanaqeen city from a sociolinguistic perspective. The main aim of this study is to investigate the conversational functions of code-switching performed by bilingual speakers in their daily oral interactions from a sociolinguistic point of view.

It is hypothesized that Kurdish people in khanaqeen code-switch from Kurdish to Arabic and vice versa to achieve a number of functions for e.g. quotation, lack of facility, reiteration etc. A model which includes seven functions for analyzing the collected data is adopted. The data that are used are collected by using audio- recording of participant conversation in various domains. The theoretical part includes the functional model which is adopted for investigating the audio -recording data while the practical part includes audiorecording and analyzing the participants' conversation. The findings of this research reveal that code-switching occurs in conversation between the bilingual speakers in the city to serve several sociolinguistic functions or reasons. In addition to these reasons that stand behind code switching, the results of analysis reveal that there are three patterns of code switching: intersentential, intra-sentential and tag switching. The results also show that the intra-sentential pattern is used more frequently than other patterns among the bilingual speakers in the city. Finally the analysis of the data confirms the hypothesis adopted in the study.
\end{abstract}

\section{Introduction}

Code-switching is a social and universal phenomenon that occurs when a bilingual speaker alternates between two or more languages, varieties of a language or even speech styles of the same language during a single communicative event. In order to achieve an effective communication, the bilingual speakers code-switch to another language and variety which is different from their mother tongues. Language as a social phenomenon has social and communicative functions through which one can investigate the role language plays in society. The impact of social factors on language choice is determined by the way society members choose varieties of a language or switch toward another code. This paper is a sociolinguistic analysis of codeswitching phenomenon between Kurdish (Luri dialect) and Arabic in Khanaqeen city which lies in the southern part of Kurdistan.

The population of the city consists mainly of Kurdish, together with two minorities of Arab and Turkmen. Kurdish is the most widely spoken language in the city, but during the establishment of new Iraq in 1922, Arabic became the official language of Iraq . Arabic strongly influenced Kurdish in most of the distributed 
areas due to the fact that Kurdish institutes were run by Arab officials .Arabic became the official language in the city until 2004. After the fall of Baath system, a new constitution was issued in 2005. According to this constitution, the two official languages of Iraq are Kurdish and Arabic. Kurdish became the official language in most of the distributed areas especially in Khanqeen till 2017. Regarding the linguistic situation in the city, most people are bilinguals.

According to Gumperz,(1982:59) codeswitching is " the juxtaposition within the same speech exchange of passages of speech belonging to two different grammatical system or subsystem". Similarly, Mesthrie, et.al (2000:14) see code-witching as "the switching back and forth of language on varieties of the same language, sometimes within the same utterance. In the same vein, Hoffmann (1991: 110) believes that "the most general description of code-switching is that it involves the alternate use of two languages or linguistic varieties within the same utterance or during the same conversation". Furthermore Poplack,(1970:200, 1980:1) states that " code-switching refers to the mixing by bilinguals or multilingual of two or more languages in discourse, often with no change of speakers or topic, such mixing may take place at any level of linguistic structure, but its occurrence within the confines of a single sentence or even word has attracted most linguistic attention" Furthermore Poplack, (1990:70) defines code-switching as the Juxtaposition of sentences or sentence fragments each one being internally consistent with the morphological and syntactic rules of its verifier language. According to Wong (1979:56) "code-switching is "the alternate use of two or more different languages, varieties of language or even speech styles within the same conversation by the same speakers." Erman, (2002:57) views code switching as a device used in a functional context in which a multilingual person makes alternate use of two or more languages". Codeswitching is also defined by Gross, (2006:144) as a complex skilled linguistic strategy used by bilingual speakers to convey important social meanings. Suan, (1990: 1) emphasizes that " code-switching originates from genetically unrelated languages to two styles of the same language. For example, a person would like to be unlikely to use similar words or phrases that (s)he would use their friends in less formal situations when speaking to their boss." According to
Wei,(2003:46), code-switching is also seen as a boundary leveling or boundary maintaining strategy that normally occurs in bilingual community settings during sociolinguistic interactions. Since codeswitching is also seen as an example of language alteration. Nilep, (2006:6) suggests that codeswitching is a communicative strategy used by speakers within a linguistic situation where two or more languages coexist within a linguistic society. The speaker switches from one communicative code to another under specific situations and conditions that may be linguistic, psychological, social, or pragmatic in nature. Hudson, ( 1980:58) describes code-switching as " alternative by bilinguals of two or more languages or varieties of the same language in their conversation. Hudson (Ibid: 56) asserts that varieties may be mixed up together in the same stretch of speech, the most obvious example of this is code switching in which a single speaker uses different varieties at different times. As Gal,(1988:247) states, "code -switching is a conversational strategy used to establish, cross or destroy group boundaries; to create, evoke or change interpersonal relations with their rights and obligations.

According to Romaine, (1992:110) codeswitching is the use of more than one language, variety or style by a speaker within an utterance or discourse, or between different interlocutors or situations. Code switching occurs mostly in bilingual communities. Speakers of more than one language are known for their ability to code-

switch or mix their language during their communication .As Crystal, (2003:79) indicates, code-switching is "a transfer of linguistic elements from one language into another, this type of alteration between languages commonly occurs amongst bilinguals and may take a number of different forms including alteration of sentences, or phrases from both languages". Auer, (1998:79) holds that codeswitching is "a code alteration because it is the alternating use of two or more codes within the same conversation. Like Auer (1998: 187), Milory and Muysken,(1995:7) say that code switching is the alternative use of two or more languages in the same conversation by linguists. They state that a switch may occur between turns of different speakers in conversation, some times between utterances within a single turn, and sometimes even within a single utterance. Muysken, (2001:7) defines code-switching 
as "alternative use of by bilingual of two or more language in the same conversation". Wardhaugh,(2010) defines code-switching as the process that occurs when people choose a particular code when they speak. According to Hymes,(1979:103) code switching is defined as the alternate use of two or more languages and varieties of language or even speech event styles. According to Iqbal,(2011) the definition of code switching is unclear, the concept itself is clear. Myers-Scotton's (2006:239, 1995:1) states that "the general definition of code switching is "the use of two language varieties in the same conversation. Furthermore, Cook,(2001:83) came up with the notion that codeswitching is the process of going from one language to other in mid-speech when both speakers know the same language". It is the systematic alternating use of two languages or varieties within a single conversation or utterance. Bokamba (1989:277-292) defines a code-switching as the mixing of words, phrases and sentences from two distinct grammatical (sub) systems across sentence boundaries within the same speech event Additionally, code-switching was viewed as a choice in determining the linguistic choices used in a conversation where the rewards and costs for using either of the languages was weighed by the switcher to achieve a particular outcome. Crystal (1987:78) views code-switching as a case where bilingual interacts with another bilingual in more than one language. Pfaff (1979: 295) states: "code switching involves some degree of competence in two languages" .Valdes (1978: 6) defines codeswitching "as the alternation of two codes on the word, phrase, clause, or sentence level". Holmes (2008: 38) also believes that code-switching can occur in the same conversation, and "when the speakers shift from one language or code to another language or code" Based on the above definitions of codeswitching, it's obvious that there are various ways of looking at the code-switching. Code- switching is used by bilingual or multilingual speakers for different purposes. More recently, patterns of codeswitching has been investigated by several researchers. Code- switching has been studied from both structural and sociolinguistic perspective.

\section{The Aims of the Study}

The study aims at finding out answers to the following questions:
1-Why do Kurdish bilingual speakers code-switch? 2-What are the types of code switching which Kurdish speakers tend to use in Kanaqeen?

3-What are the most crucial functions of codeswitching?

\section{Literature Review}

Some researchers argue that further studies on the phenomenon of code-s witching from a sociolinguistic perspective in various contexts are still needed to gain a more clearly defined sociolinguistic explanation of the phenomenon of code switching. Malik,(1994) in his study on the code switching in a social network lists ten reasons for code-switching: to show solidarity, lack of facility, lack of competence, semantic significance, to address different audience, to amplify and emphasize a point, mood of the speaker, habitual expressions, pragmatic reasons, and to attract attention.

A research has been done by Sharaf-Eldin(2014) to cover and analyze the phenomenon of codeswitching in online interaction. It was found out that code-switching does not occur only in conversation, but also in the electronic discourse. The findings of this study show that there are three kinds of code switching: tag switching, inter-sentential switching and intra-sentential switching that serve to achieve an effective communicative. The study explains the main functions and reasons behind the use of codeswitching by Arabic English bilinguals in their face book interactions.

Another study by Mahmood \& Ahmed (2012) investigated code-switching in Kurdish SMS messages. It was found out that there are three main types of code-switching use by Kurdish in their electronic interactions. The findings also reveal a number of reasons that stand behind the use of codeswitching. Mannal, (2015) in her study investigates the functions of code-switching that occur in casual conversations by young bilingual Saudis.

Another study by Nabaz,(2016) investigated the reasons of code-switching in conversations by bilingual and multilingual speakers from a sociolinguistic perspective. Another study by PurMuhammad (2015) investigated the production of code switched utterances in bilingual speech production .Furthermore, Muhammad (2015) studied the use of code-switching in formal Iraqi dialect among Iraqi Arab speakers of English. The study 
affirmed that the reason behind the use of code switching is due to the lack of proficiency in first language, impact of technological devices and the linguistic factors.

Recently, Al-Hourani(2016) investigated the bilingual Jordanian speakers' use of code- switching in their daily conversation from a sociolinguistic point of view. It was found out that there are many reasons behind the use of code-switching. The study also explains the three most important patterns of codeswitching: inter-sentential code switching, intrasentential and tag switching. As discussed earlier, the phenomenon of code-switching has been tackled by many researchers over the world. Concerning Kurdish, very few researches on code-switching has been done by the Kurdish researchers particularly in the southern part of Kurdistan. Therefore, this study was conducted to fill in this gap in literature.

\section{Types of Code-Switching.}

According to Poplack,(1980:614); Both Muysken (2000:99) and Hoffmann (1991:112) There are three types of switches that can occur in the same discourse.

\section{a-Inter-sentential switching.}

This type of code-witching occurs at sentence, clause boundaries to reemphasize a certain point uttered in another language. In other words, it occurs at clausal or sentential level where each clause or sentence is in one language or another occurring within the same sentence or between speakers' turns. This type requires its speaker to be fluent in both languages in order to produce the grammatical sentences without violating the syntactic rules. According to Romaine (1995:122-123), this pattern can occur across sentence, clause boundaries or between speakers' turns. This kind of code-switching helps us to recognize to whom the speech is addressed through which the bilingual speaker can convey a direct quotation from another .It requires more fluency in both languages, as each part of the utterance must agree with the rules of the corresponding language being spoken.

\section{b-Intra- sentential switching.}

The bilingual speaker who uses this pattern of code switching should have a high level of facility of two languages. The speaker should have enough knowledge about the grammar of both languages because this type requires the speaker to be more fluent and have more proficiency in the two languages. This kind of code switching occurs in the middle of a sentence unconsciously without pauses, breaks or hesitation to keep the continuity of conversation. Jalil (2009:4) holds that intra- sentential switching is the most complex among the three. It can occur at clausal, sentential or even word level. The speaker is usually unaware of the switch when involves in conversation. Furthermore Romaine (1995:122-123) says that this pattern occurs within sentence, clause, and word boundaries.

\section{c-Extra- Sentential or (tag switching).}

Poplack (1980: 589 as cited in SharafEldin, 2014:82) explains that this pattern involves "inserting a tag from one language into an utterance that is otherwise in another language." Tag switching involves inserting words or phrases which include interjections, fillers, and idiomatic expressions from one language to an utterance entirely in the other language without violating syntactic rules when being inserted into monolingual sentences because the inserted tag has usually syntactic restrictions that suit with monolingual

Language (Hammers and Blanc 2000: 259). (E.g. you know, I mean, right)

Functions of Code-s witching.

According to Gumperz, (1982:75-77(code-switching has six basic functions

1-Quotation: code switching is used to distinguish direct quotation from reported speech. (dear Jamal, either u use the abbreviated form CS throughout the paper or use the full form) CS occurs when someone else's utterance is reported either as a direct quotation or as reported speech, i.e., a bilingual speaker codeswitches by using an utterance which is different from the one in which the originate utterance was made.

2-Reiteration: code-switching occurs when a bilingual speaker repeats a message in the code to clarify what is said. The speaker repeats exactly what he says in another language for the purpose of emphasis or to clarify what is said. This pattern of function can be used to achieve an effective communication. For example, a Spanish/English bilingual mother may call her children who are playing on the street first in Spanish, but if they do not listen, then in English. 
3-Addressee specification: the switch serves to address a particular person among several addressees present in immediate environment. The notion of CS serves to exclude or include someone from a part of conversation.

4-Interjection: switching occurs consciously or unconsciously to serve as sentence connectors or sentence filler, the speaker trying to insert a tag from one language to another. This type is also known as injections or sentence fillers such as tags and discourse markers.

5-Message qualification: Gumperz, (1982:74) defines message qualification as "an elaboration of the preceding utterance in the other code".

6-Personalization versus objectification: This pattern of function is employed to make a distinction between conversation as action and conversation about action. This type of code function refers to the degree of speaker involvement in a message as in the case of giving one's statement more authority in a dispute through code switching.

Reyes (2004:84) in his study on school children's conversation used eleven functions of CS: 1-Representation of speech: CS is employed to represent talk.

2-Imitation quotation: CS involves imitation and change in tone of voice to play a particular character.

3-Turn accommodation: CS occurs between speakers' turns.

4-Topic-shift: CS occurs due to a change of topic in conversation.

5-Situation-switch (on/off topic in academic work): CS marks a switch between science talk and nonscience talk.

6-Insistence (non-command): CS indicates a child's persistence in a specific idea. The child usually repeats the same utterance in both languages.

7-Emphas is (command): CS is used to put emphasis on a specific command.

8-Clarification or persuasion: CS gives more information to clarify an idea or message.

9-Pers on specification: CS occurs when children refer to another person during their conversation.

10- Question shift: CS indicates a switch in language when children have a question.

11-Discourse marker: discourse markers are linguistic elements that do not necessarily add to the content of the utterance but act as markers of the context in which the utterance is taking place (Escalera, 2002)cited in (Reyes,2004:85).

\section{Reasons behind Code-switching.}

Crystal (1987) cited in (Skiba, 2016:1) states three reasons for the switching from one language to another language.

1. To compensate for the deficiency: the speaker may not be able to express him/herself in one language so (she) switches to another language or variety to compensate for the lack of proficiency in that language. As a result, the speaker may be triggered into speaking in another language for a while. Crystal (1987) cited in (Skiba, 2016:1). As Crystal,(1987) noted that "This kind of function occurs when the speaker is upset, tired or confused in some manner 2.To show Solidarity: code-switching is used to show solidarity with a particular social group, and degree of comfort would exist amongst the speakers in the knowledge that not all present are listening to their conversation.

3.Expressive: code switching occurs when the bilingual speaker wishes to convey his or her attitude to the listener while the monolingual speakers can communicate these attitudes by means of variation in the level of formality in their speech.

According to Hoffman (1991:113), codeswitching is used to:

-talk about a particular topic

-quote somebody else

-provide emphasis about something (to express solidarity)

-make an interjection (by inserting sentence fillers or sentence connectors )

-repeat in order to clarify

-express group identity

-show intention of clarifying speech content for interlocutor

-soften or strengthen a request or command

-meet a real lexical need or to compensate for lack of an equal translation

-exclude others when a comment is intended for an exclusive audience

Malik,(1994) lists ten reasons for code -switching which are: to show solidarity, lack of facility, lack of competence, semantic significance, to address different audience, , to amplify and emphasize a point, 
mood of the speaker, habitual expressions, pragmatic reasons, and to attract attention.

Another study was done by Sharaf-Eldin,(2014: 80) on social network to discuss the most common reasons behind the use of code switching by Arabic language speaker on social network. The researcher focuses in his analysis on five reasons which stand behind the use of code switching in conversation between the Arabic speakers.

1-Affection: code-switching can be used by speakers to express certain feelings and attitudes. Speaker may code-switch to express happiness, excitement. Anger, sadness, and many other feeling. Holmes (2000) says that language switch is often using to express disapproval. So a person may code-switch because (s) he is angry.

2-To reflect social status: according to Suleiman (1999) the speaker tends to use a different language to imply a certain social status to distinguish themselves from other social classes. The phenomenon of codeswitching can be looked upon as a way to distinguish oneself and as something prestigious and as assign of education and competence in more than one language. 3-To Show Solidarity. In her book "Introduction to Sociolinguistics", Holmes (2000) mentions that, "a speaker may switch to another language as a signal of group membership and share ethnicity within an addressee". Code-switching can be used to express solidarity between people from different or the same ethnic groups.

4-To persuade audience: according to Holmes (2000), code-switching is often used in speech and rhetoric, on purpose in order to either attract attention and to persuade an audience. Nerghes (2011) comments on the effect of code-switching in persuasion and its ability to grab the attention of the audience by saying, 'code-switching will draw the participant's attention and will increase their motivation to carefully analyze the message presented.

5-Topic: topic is to be another important reason that leads a bilingual speaker to code-switch. Leung,(2006) states that " taboo words and topics are often code switched so as to a void to be expressed in the speaker's native language"

\section{Model of Analysis}

Based on the functions and reasons listed above by Gumpertz (1982), Malik(2016), the researcher adopted the model shown in Figure (1) which includes three types of code- switching and (7) functions to discuss the occurrences of code switching among Kurdish bilingual speakers in Kanaqeen.

Table (10) Elements of the adopted model

\begin{tabular}{l|l}
$\begin{array}{l}\text { Type of code } \\
\text { switching }\end{array}$ & \multicolumn{1}{|c}{$\begin{array}{c}\text { Function of code } \\
\text { switching }\end{array}$} \\
$\begin{array}{l}\text { Intra-sentential } \\
\text { code switching } \\
\text { Inter-sentential } \\
\text { code switching }\end{array}$ & 1-Quotation \\
Tag switching & 2-Attract \\
& attention \\
& 3-Emphasis of \\
& facility of \\
& 5-lack \\
& registers \\
& 6-Reiteration \\
& 7-Interjection
\end{tabular}

\section{Analysis of Data \\ Conversation No 1}

\section{Setting: College of Arts}

Situation: two students are discussing the latest examination

Tara: (دويكه له ئيمتحان جوين جاهو ابدايت). .

How was the exam yesterday?)

During the conversation the speaker uses the intrasentential type of code switching to achieve an effective communication. She code-switched to Arabic when she used two Arabic terms " Imtahan'(امتحان) which means 'exam' and 'jwab). The speaker cannot get the appropriate terms in her native language at the moment of speaking that's why she code switched to compensate for the lack of knowledge in L1.

\section{Lezan. الحمدله خاس بوى}

(Thanks for Allah it was good).

The addressee tends to use tag switching pattern when she code-switched to Arabic and inserted the phrase "alhamdu lila" this expression is frequently used by Muslims. The term is used as sentence filler without violating the syntactic rule of monolingual sentence.

Tara: راست ئويشى اسئلهكه مركز بى. 
(You are right, the question was very comprehensive.)

The speaker code-switches to Arabic during the conversation and used two Arabic terms" سنئله "which means question and "مركز" which means comprehensive. The speaker resorts to intrasentential type of code-switching to carry on conversation smoothly. The reas on behind using these Arabic term is that the speaker unable to find the appropriate terms in native language at the moment of speaking because she is upset about the results of the exam. This point is supported by the Crystal, (1987) claims that "the speaker switches to other language or variety to compensate for the lack of proficiency in that language.

\section{Lezan: ديرى و اتساٌ}

(Do you have What Sapp?)

Tara: نه والله و اتسابٍ نهيرم بر امجاكان كوشانسمهو مى باس قايير دي

(No, swear by Allah, I don't have what's app, I deleted all programs, I have only viber.) During the conversation the speaker' used the intrasentential pattern of code switching. The interlocutors code switch to English when they use the English terms 'whatsapp and Viber. Since these two terms are not available in the two languages ; Kurdish and Arabic, that's why the interlocutors code switch to English to compensate the lack of register. Furthermore the technology has played the important role in the use of English terms because both languages lack these technological terms, like viber, face book, imo, instigram, skyp, whatsapp, and etc.

In addition to these technological terms, the speaker code-switches to Arabic when she uses the 'na wallah', which means 'no, I swear'. This term is a tag switching which is used as sentence filler, but here it has the function of emphasis. The Arabic term "برامج" is used by Tara during the conversation. She alternates between the two languages because she lacks facility and she could not find suitable item in Kurdish at the time of speaking.As a result she resorts to Arabic terms for compensate of the lack of proficiency and to keep the continuity of conversation.

\section{Conversation No2}

Setting: English department frankly

Situation: Two lecturers talking about the scientific title

Zeinab: ماموسا لقب علمى ديري؟ و ور اس

(Frankly, Miss Lara, Do you have the scientific title?)

Lara: باللي لقبم هاسس

(Yes I got it last year.)

Zeinab: له كاملا.

(Where did you get it)?

Lara: له كوليه بيلاد ر افدين الجامعه

(College of Bilad Al-Rafidein.)

Zeinab: ئايا كر ائق تدريس خو هنسنيه؟.

(Did you study the methods of teaching?)

Lara: كر ائق تدريس له باقوبه خو هنستمساهى.

(I studied methods of teaching in Baquba.)

During this conversation, the speakers code-switch to Arabic when they use intra-sentential type of code switching. It can be argued that the speakers use the Arabic terms in the conversion because Kurdish in these areas is strongly affected by Arabic due to the fact that the Kurdish institutes were run by Arab officials for nearly ten decades and the city subjected the process of Arabization. Since Kurdish has لقب علمي، كليه، / equivalent terms for these Arabic terms but the interlocutors use them in their daily communication. The reason behind this wider use of Arabic terms may be due to the lack of knowledge in their native language.

\section{Conversation N0.3}

Setting: restaurant

Situation: two teens talking about earth quake that happened five minutes ago.
Ali: حس كردى ومزوى للرزمكه؟.
( You felt the earth quake?)

\section{Huss ein:نه، دويكه؟}

(No, yesterday?).

Ali:. نه، ئيسه بلهله ينج دمقيقه

(No, five minutes ago)

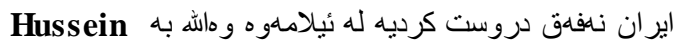

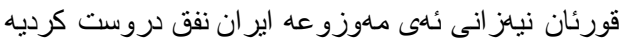

(Iran has made a tunnel from Ilam. Swear by Allah, Quran don't you know this subject?

Alai:. نة واله

(No, swear)

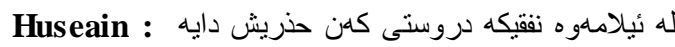

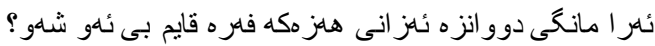


(Iran tries to make a tunnel from Ilam and warned for the

December. Do you know that the earth quake was so strong last night?

During the conversation the speakers use intrasentential type of code switching when they tend to

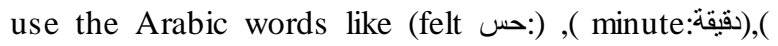

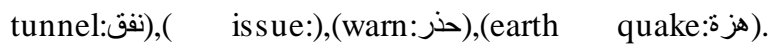
Moreover, this kind of intra-lexical (within word boundary) occurs simply to fill the gap in conversations. Many Kurdish speakers in the city switch within word boundary in their conversations because they cannot find the exact word in their native language at the moment of interaction or they habitually use these terms in Arabic language. It is clear that the process of Arabzition in the distributed areas has influenced the use of code switching among the Kurdish people in Khanaqin. For this reason code-switching within word boundary has become a common phenomenon in conversation. This point is supported by Mahmood \& Ahmed ,(2016:122) who state that Kurdish speakers feel forced to code switch to other languages mainly Arabic and English either they don't Know the terms in Kurdish as they are unable to find the terms in their native language or they find it easy to say the words in Arabic.

After the investigation of the conversation the researcher found that speakers switch to Arabic when they use religious terms like (والله، وقران) swear by God and by the holly Quran. It's clear that the majority of Kurds are Muslims and they are affected by the language of Holy Quran, that is why they switch to Arabic. Here the speaker use these two terms for the purpose of emphasis. Both of these two code-switched items are tag switching type.

\section{Conversation No 4}

Setting: oil change shop

Abbas: سلام عليكم

(peace be upon you)

Diar: هلو عباس كيان

(Hello my soul)

Abbas: رؤزى بِهنج شامده سوير كهم له قاعهكهى ئاغا I have weeding in Agha Hall on Thursday

خير داره.Dyar

(It's good)
Abbas: سلامت بويت، بايته خوت و عائلهكهت باينه : ئسر اي سوير ككه:

(Be safe dear. You and your family should come to weeding).

Diyar: ان شاءاله (God willing)

Abbas: مجال ديرى

(Do you have chance?)

Diyar: ان شاءالله، ان شاءالله

(God willing, God willing)

Abbas: هامه خزمهنان وه اول نفر هاتمهئمر ا لاى تو

('I will serve you, you are the first one I visited)

Diyar: قوربانت

(God blessed you).

Abbas: وه باييته سبار مكهيثه روينهكهى ئهرام بدل بكهى بشووريتهى نئهر ام جوان

(You should change the oil of car and wash it well).

Diyar: وهبان سار امر كهى دلل

(pleasure by all means).

Abbas: ئلهو سيار هةكهيه.

(That's the car)

During the conversation the first speaker uses the tag switching type of code switching to fill in the gap by an appropriate word in his conversation as a communicative intent. When he code-switches to Arabic and uses the religious term سلام عليكم which means 'God blessed upon you'. This greeting term is used frequently by all Muslims to show solidarity. Here, the speaker wants to attract the attention of the shop owner and to achieve the socio-cultural function of switching. The listener uses "the English term "Hello" for greeting" it clears that this term is used recently among the young people in the city as an emblematic switching or interjection to fill the gap in utterances as a communicative event.

The interlocutors code-switches to Arabic when they use emblematic type of switching.

The Arabic item 'ان شاءالهة which means 'God willing' is used as gap filler without violating the syntactical structure of L1. In the line 8 the speaker repeats this religious item not only as sentence filler, but for the purpose of emphasis. On the hand, the occurrence of code-switching can be observed when the speakers tend to use another type of code switching as intrasentential. The speakers use the following Arabic اول، نفر، قربان، بدل و ( (سيارة خير، عائلة، قاعة، سلامة،مجال using these terms as mentioned before is that the speakers are affected by the policy which was 
followed by the former regime. For this reason they code to Arabic when they could not find equivalent words for Arabic terms in Kurdish at the moment of speaking. This point is supported by Crystal (1987) who states that " the speaker may not be able to express him/herself in one language, so (s)he switches to another language or variety to compensate for lack of proficiency in that language.

\section{Conversation No.5}

Setting: inside the city

Situation: the father looking for his son to take him to polling center and they met each other outside the house in the city.

The son: ئر ا كوجى؟

(Where are you going?)

\section{The father:}

(Where are you?)

The son: لله سار شار عاكه بيم ليره

(on the street, here)

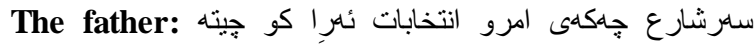
(what are you doing on the street to day is election!)

The son: انتخابات جه كوره بيلهمان خودا. باهوهمالّ تو بيمارى (Leave us alone for God's sake and come home, you are sick, what is election!?

The father: نيهجمه مال من تو ام تصويت بيام، دمنگ بيهم.

(I want to vote, I do not go home).

The son: انتخابات جه تو بيمارى، سكر ديرى، ضغط ديرى جلطه ديرى. باوه مال باوه مال

(What election! You are sick; you have diabetes, blood pressure, heart attack, come home come home).

The father: به خودا تانهيت و وليم نيهجم ( swear by God if you don't come with me I don't go).

The son: ورةاله نبهجم swear by Allah I don't go.

The father: جى

(what?)

The son: نيهجة I don't go.

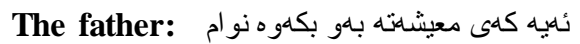

(This is not living, come with me)

The son: كي انتخاب كميت؟.

(To whom do you vote?)

The father: انتخاب قائمسى تحالف كردستاني (vote to the Kurdistan alliance list)

The son: رقاهماكه جهنده؟

(What is the list number?)

The father: 372
During the conversation the interlocutors code-switch to Arabic and they use intra-sentential code-s witching and tag switching. Regarding the first type, the speakers code- switch to Arabic when they use the following terms

شارع، انتخاب، خاطر الله، تصويت، انتخابات، سكر، ضغط، جلطة، ، 'معن، The reason behind this code-s witching is that the speakers are unable to get the corresponding words in Kurdish that's why they alternate between the two languages. The father is upset. This leads him to use Arabic items when he uses the inter-sentential switching type to achieve the expressive or affection function of code switching. This point is supported by Holmes,(2000) who states that language switch is often used to express disapproval, so a person may code-switch because he is angry. The speaker uses the word vote in Arabic and then in Kurdish, because he wants to reemphasize a certain point. On the other hand, the speaker uses the tag or emblematic switching when he code-witches to the Arabic religious phrase 'و الهّ' to emphasize that he does not want to vote.

\section{Conversation: No 6}

Setting: Park

Situation: group of graduated student talking about the case of employments

Abbas: تعينات كرياساهو

(does they employ people now?)

Azad: والله عباس كيان نياز انم من زنفتمه ئويشن تعينات موجوده (actually I don't know, I heard that they do employ people)

Abbas: : ئهى بيشماهركه يان نُاسايش؟

(Peshmarga or Asaish (security )?

Azad : واله نيهز انم بهس ثيوشن له بان مركزيت تعينات هلس.

(I don't know, but they say that the Iraqi government employs the people.)

Abbas : بويشه وه بر اخهت نا ناوبنويست.

( Tell your brother to register his name.)

Azad: ئا من بر اكهم كميك تر نارمه تعينات

(yeah, after a moment I will send my brother to apply)

The speakers code-switches to Arabic during their interactions. This conversation contains five Arabic words. Two of them are identical "Walla: واله". This religious term is a tag switching type. The speaker uses this Arabic item for the purpose of emphasis. The interlocutors use also two identical words ( تعينات both of these code switched terms are intrasentential. They are used by the speakers because they 
lack the equivalent words in their native language. Some other items are used like, موجود، مركزي (central, existence). The speakers couldn't find the corresponding Kurdish words for the two Arabic expression for this reason they switched to Arabic to compensate the lack of proficiency.

\section{Conversation: No 7}

Setting: at home

Situation: father is thirsty and asked his little daughter 'Huda' to bring him a glass of water.

Sherko: هدى كلاسيك ئاو باره نئر اى باوه (Huda, bring a glass of water to your dad)

Huda: بئي باوه نيسه نيام

(Yeah, Dad I'll come)

Sherko: هدي و ونت بيت كَاسيك ئاو بار

(Huda, I told you to bring a glass of water)

Huda: باوه جهنو اسنتي؟

(What do you want, Dad?

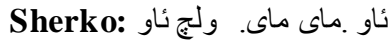

(Oh, my daughter, water, water. Bring a glass of water to me.

Huda:

$$
\text { (yeah, yeah, dad, good.) }
$$

The analysis of the conversation reveals that the father code-switches to Arabic and uses inter-sentential type of code switching for the purpose of reiteration. The father askes his daughter to bring a glass of water, but she does not care to his father that's why he becomes angry and repeates the same expression in Arabic language to attract her attention. The English word glass is also used by the speaker because this intra sentential type is habitually used by Kurdish and Arabic people in Iraq. Since there are equivalent words for the word in both languages but the English term is used in daily communication in the city habitually.

\section{Conversation: No 8}

Setting: office of school director

Situation: one of the teachers addressed the director and asked him about daily affairs.

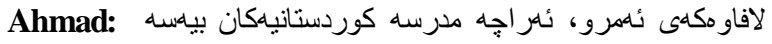
عطلاه ئيمه نـه

(Because of the flood, in all Kurdistan schools today is off day but here is not.

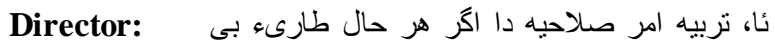
يعنى مدير مدرسه تو انت بكائته عطله

(Yeah, the directorate of education issued an order whereby gave us authority to make it off day if the state of emergency happens).

Ahmad: مدير مدرساككه؟

(You mean the director of schools can make it off day.

Director: ئا، ئا صلاحيهت دانه بيمان له مديريه عامه" اي حاله يضر امن طلبه" بكريهت هاله

(Yeah,yeah,the general directorate gave us the authority to make it off day if we expect any situation that harms the students.)

Ahmad: اي خاس ئهو ان طلبه ديرن ئيمه طلبه نسيريم

(Ok, they have pupils, we don't have!?)

During the conversation the speakers code-switch to Arabic and use two three types of code-switching, inter-sentential code switching, intra-sentential codeswitching and tag switching. Concerning the first type, the speaker code-switches to Arabic when he says اي حاله يضر امن طلبه" To achieve the quotation function, he quotes a part of the decision issued by directorate of general education in Arabic language to focus on a certain point. Regarding the intra-sentential the speakers also used the following Arabic words, (مدرسه، عطلة، صلاحيات، طلبة، مدير، مدير ية عامة). Kurdish has the equivalent words for these six items, but the participants in conversation code switched to Arabic. The reason behind this alternate is the fact that the Kurdish people in the Khanaqeen are influenced strongly by Arabic. The code-switched words are frequently used because they feel that it's easy to pronounce and economic in expressing rather than their native language. Thus, the alternate between the two languages in conversation consciously or unconsciously does not violate the syntactical rules of Kurdish. The people have been familiar with these words when they speak keep the continuity of conversation without any break or hesitation. There is only one tag switching words in conversation. The speaker used the Arabic word (يعنى (which means (I mean) to fill the gap and to keep continuity this point is supported by polack(1982) says " This type of code switching occurs the most easily for the reason being that tags typically contain minimal syntactic restriction that not violating syntactic rules when being inserted into monolingual sentences such as ( I mean, you mean). 


\section{Conclusions}

The findings of the study lead to the following conclusions:

1- Code-switching is a natural phenomenon occurring in the bilingual community of Khanqeen

2- The speakers code-switch to create an effective communication.

3- There are many functions and reasons that stand behind the occurrence of CS in conversation between the Kurdish Arabic speakers in Kanaqeen.

4- There are three types of code switching which Kurdish people tend to use in their daily communications. Intra-sentential code switching, tag switching, and inter-sentential code switching.

5- Intra-sentential type is the most frequent use in the conversation due to the fact that Kurdish is affected strongly by the process of Arabization and the users have more proficiency to use the Arabic item unconsciously without violating the Kurdish syntactic rules.

6- Inter-sentential type is rarely used by the people in conversation.

\section{References}

1. -Abdel Jalil. S. 2009. "Grammatical perspectives on code-switching". ReVEL, vol. 7, n. 13.

2. -AL-Hourani, A.\& Nur Afizah, T. 2013. "Code switching in daily conversation". International Journal of Social Science and Humanities Research. Vol. 1, Issue 1, pp: (40- 43).

3. -Auer, P. 1998. "Code-switching in Conversation: Language, Interaction, and Identity". London: Routledge.

4. -Bokamba, E. G. 1989. Are there syntactic constraints on codeswitching? World Englishes8, 3: 277-292.

5. -Cook,V.J. (2001). Using the first language in the classroom. Canadian Modern Language Review, 57, 403-423.

6. -Erman, B. 2002. "Issues in Code-Switching: Competing Theories and Models". Papers in Linguistics.Columbia University. Vol. 17. Pp.2227

7. -Gal, S. 1979. "Language Shift: Social Determinants of Linguistic Change in Bilingual Austria". New York: AcademicUniversity of Pennsylvania Press.
8. -Gal, S. (1988). The political economy of code choice. In Heller, M. (ed.) , Code switching: Anthropological and sociolinguistic perspectives (pp. 245-264) Berlin: Mouton de Gruyter.

9. -Gross, S. 2006. "Code-switching. In the Encyclopedia of language and linguistics".

10. -Gumperz, J. J. 1982. "Conversational code switching in discourse strategies". Cambridge: Cambridge University press.

11. -Hamers, J. F., \& Blanc, M. (2000). Bilinguality and bilingualism. New York, NY: Cambridge University Press.

12. -Hoffmann, C. (1991). An introduction to bilingualism. London: Longman

13. -Holmes, J. (2000). An Introduction to Sociolinguistics (2nd ed.). Wellington: Longman

14. -Hudson. R.A. (1980).Sociolinguistics, Cambridge: Cambridge University Press.

15. -Hymes, D. (1979). On communicative competence. In K. Johnson \& C. Brumfit (Eds.), The Communicative Approach to Language Teaching. Oxford: Oxford University Press.

16. -Iqbal, L. 2011. "Linguistic Features of CodeSwitching: A Study of Urdu/English Bilingual Teachers' Classroom Interactions". International Journal of Humanities and Social Science Vol. 1. P. 188-194.John Benjamins Publishing Company, USA.

17. -Leung, C (2006). Code Switching in Print Advertisement in Hong Kong \& Sweden MA Thesis, Lunds Universtite, Linguistics and Phonetics.

18. -Malik, L. (1994). Sociolinguistics: A study of code switching. New Delhi: Anmol

- $\quad$ Mesthrie, R., Swann, J., Deumert A., \& Leap, W. L. 2000. "Introducing sociolinguistics.

19. -Milroy, L., \& Muysken, P. (1995). Introduction: Code-switching and bilingualism research. In $\mathrm{L}$. Milroy \& P. Muysken (Eds.), One speaker two languages: Cross-disciplinary perspectives on code-switching (pp. 1-14). New York: Cambridge University Press.

- $\quad$ Myers-Scotton, C. 2006. "Natural codes witching knocks on the laboratory door". Bilingualism: Language and Cognition, 9(2), 203-212.

20. -David, M. (2001). The Sindhis in Malaysia: A sociolinguistic study. Michigan: the University of Michigan. 
21. -Nerghes, A. (2011). The Impact of CodeSwitching on Persuasion: An Elaboration Likelihood Perspective. Wageningen University.

22. -Nilep, C. 2006. "Code Switching" in Sociocultural Linguistics". Colorado Research in Linguistics. University of Colorado. Vol. 19. Pp.12.No. 6.

23. -Poplack, S. (1980). Sometimes I'll start a sentence in Spanish y termino en espaniol: Toward a

24. -Pfaff, C. (1979). Constraints on language-mixing: Intra-sentential code-switching and borrowing in Spanish/English. Language, 55, 291-318

25. -Reyes, I. (2004). 'Functions of Code Switching in School Children's Conversations'. Bilingual Research Journal, 28, 83-96.

26. -Romaine, S. (1992). Bilingualism. Blackwell Publishers: Cambridge

27. -Romaine, S. 1995. "Bilingualism". 2nd edition. Oxford: Blackwell.

28. -Sharaf Eldin, A. 2014. "Socio Linguistic Study of Code Switching of Arabic Language Speakers on Social Networking". International Journal of English Linguistics; Vol. 4, No. 6.

29. -Skiba, R. (1997). Code Switching As a Countenance of Language Interference. The Internet TESL Journal. Vol. III. No: 10.sociolinguistics". Edinburgh: Edinburgh University Press.
30. -Suleiman, Y.(1999). Language and the Society in the Middle East and North Africa: Study in Variation and identity.UK. Curzon Press.

31. -Suan, O.K. 1990. "A study of code switching among bilingual Malay students in certain urban

32. secondary schools". unpublished master thesis. Kuala Lumpour: University Malaya.

33. typology of code-switching. Linguistics, 18(78), 581-618

34. -Valdes-Fallis, Guadalupe. 1978. "Code-Switching and the Classroom Teacher." Language in Education: Theory and Practice. Vol. 4. Washington, DC: National Institution for Education.

35. -Wardhaugh, R. 2010. "An Introduction to sociolinguistics". Malden, MA : Wiley- Blackwell.

36. -Wei, L. 2003. "The 'why' and 'how' questions in the analysis of conversational code-s witching". In P. Auer (ed.). "Code-switching in conversation: language, interaction and identity". pp. 156-76. London: Routledge

37. -Wong, I. 1979. "Code-Switching in Bilingual Contexts: A Malaysian Perspective". Singapore: Regional Language Centre. 